\title{
Application of Environmental Information Systems in Environmental Impact Assessment (in Hungary)
}

\author{
Veronika ELEKNÉ FODOR ${ }^{*}$ - József PÁJER \\ Institute of Environment and Earth Sciences, Faculty of Forestry, University of Sopron, Sopron, Hungary
}

\begin{abstract}
The primary research aim was to explore the possibilities of transferring relevant data from information systems and databases required for practical environmental impact assessment. The necessary and adequate data content of environmental impact studies were defined according to legal regulations, expert recommendations as well as available impact studies. Furthermore, the data content of information systems pertinent to environmental impact analysis were investigated in view of data transmission. Disposing of the primary data required for impact studies, the classification of environmental objects (object class, object group, object type) was performed. Based on the latter, a pattern system design was completed; in the course of developing this, we defined the individual system overlays in the theoretical model, then assigned properties of the individual object types in the database model.
\end{abstract}

environmental impact assessment / environmental database / information system / system design / data model

Kivonat - Környezeti információs rendszerek alkalmazása a környezeti hatásvizsgálatok során. A kutatás elsődleges faladata a környezeti hatásvizsgálat gyakorlati kivitelezéséhez szükséges adatok információs rendszerekből, adatbázisokból való átvételi lehetőségének vizsgálata volt. Jogszabályi elöírások, szakirodalmi ajánlások valamint már elkészült hatástanulmányok vizsgálata alapján meghatározásra került a környezeti hatásvizsgálatok szükséges és elégséges adattartalma. Vizsgáltuk továbbá a környezeti hatásvizsgálatok szempontjából relevánsnak tekinthető információs rendszerek adattartalmát illetve az adatátvétel lehetőségét. A hatástanulmányokhoz szükséges primer adatok ismeretében elvégeztük a szükséges környezeti objektumok osztályozását (objektumosztály-, csoport, típus). Ennek ismeretében egy minta rendszertervet dolgoztunk ki, amely során az elméleti modellben meghatároztuk a rendszer egyes fedvényeit, majd ezt követően a logikai adatmodellben megadtuk az egyes objektumtípusok tulajdonságait.

környezeti hatásvizsgálat / környezeti adatbázis / információs rendszer / rendszerterv / adatmodell

\footnotetext{
* Corresponding author: elekne.fodor.veronika@uni-sopron.hu; H-9400 SOPRON, Bajcsy Zs. u. 4, Hungary
} 


\section{INTRODUCTION}

Prior to implementing, abandoning, or significantly extending establishments and operations that fall within the scope of certain conditions, conducting environmental impact assessments (EIA) are often required by law; even if there is no legal obligation for an EIAs, it is highly recommended as a precautionary measure (Elekné Fodor 2012). Since its introduction in the early 1970s, the role and scope of EIAs are continuously expanding, although its application, practice, and procedures vary from country to country (Lee 1995). Between 1994 and 1997, the number of environmental impact assessments submitted to the authorities in Hungary increased by an average 10\% annually. There were more than 500 impact studies in 1997 (Pájer 2001); by 2005, this number exceeded 750 (Cseh at al. 2007).

The objective of an environmental impact assessment is to explore environmental impacts and to assess and demonstrate the resulting changes that can ensue from given human activities and their products (Pájer 1999, Chen 2014). By this method, environmental requirements have a better chance of prevailing in the course of decision-making (Glasson 1995, Rédey - Utasi 2004, Cserny et al. 2009). Generally, an impact study is an information collection and analysis process; thus, up-to-date, available, and relevant data are needed to attain useful results (Bulla et al. 2004). The importance and necessity of data is emphasized in the basic principles of an environmental impact assessment; the realisation of an EIA is only possible if the appropriate quantity and quality of data is available. Fortunately, when it comes to environmental impact studies, a rise in the quantity of studies conducted has also led to a rise in quality (Barker - Wood 1999).

One of our research objectives was to explore the primary environmental descriptive data that is both necessary and appropriate for the demonstration of the state of elements in the environment and for the probable effects assessment in the course of environmental impact studies. The data list we compiled contained the data needed in most environmental impact analyses. We set a further objective for investigating the data content, availability, and possibility of data transmission of information systems relevant to our research.

Science and engineering research will produce increasingly more scientific data. Databases and information systems are also increasing. They are used to describe the state of the environment and to track the impact individual companies have on the environment and to ensure these companies adhere to environmental protection goals (Dedrick 2010). Using this data successfully depends on the ability to access, integrate, and analyse these large databases (Tarboton et al. 2009). Environmental decision support systems as well as participatory environmental decision making also require a database that incorporates and allows dynamical incorporation of interdisciplinary expert knowledge (Bianconi et al. 2004). These have motivated more global initiatives to build spatial data infrastructures (Masser 1999, Kok - Van Loenen 2004) to facilitate the collection, maintenance, dissemination, and use of spatial information (Lagacherie et al. 2007, Bulla 2012). National and international initiatives aimed at building accurate data infrastructures increasingly call for standardized, harmonized, and up-to-date information. For example, INSPIRE (Infrastructure for Spatial Information in the European Community) encourages local and national contributors to apply standards of data format and quality to combine their information with information from other sources (Jensen et al. 2004). Comprehensive environmental information can be propagated to the public via the internet rapidly, simply, and in real-time (Schimak 2003).

In the light of the above, our task was to lay down the foundations of an information system that can support the data acquisition process of environmental impact analysis in view of the general list of data and the contents of relevant information systems. 


\section{MATERIAL AND METHODS}

\subsection{Exploration of the general data requirement of environmental impact assessment}

The first step of our research was to study the specifications relative to data contained in EU and domestic laws pertinent to environmental impact analysis. We explored the relevant literature; moreover, we followed the method used by Hemann et al. (2007) and analysed the documentations of completed impact studies. In the course of our investigations, we examined 62 environmental impact assessments, of which 40 were preliminary examination documentations and 22 were completed environmental impact studies. Most of the impact assessments for investigation were randomly selected through electronic search (89\%) as well as the studies conducted by the Institute of Environment and Earth Sciences of the University of West Hungary.

The data analysis is based on data collection, performance indicators, and data quantification (Wang et al 2014). In the course of investigation, we determined general primary environmental data that the law prescribes or recommends, or that were actually used by the authors of the examined environmental impact studies. On this basis, a data list was compiled containing only those data fields that occurred with at least $75 \%$ frequency in the examined impact studies as a result of statistical evaluation.

Besides the general list of data, the data requirement of a concrete type of establishment (roads) was explored in order to examine the deviations due to special data requirements, or, in other words, the usability of the general list of data. The investigations by Forman (2000) call the attention to the impact roads have on the environment. Since a notable part $(40 \%)$ of the documents related to roads (Table 1), and we ourselves were concerned with environmental impact studies of this type in our professional work, the data requirement of these type of establishments was defined in our establishment-specific examinations.

Table 1. Distribution of the examined Environmental Impact Assessments according to their subject

\begin{tabular}{lc}
\hline Subject of EIA & Number of examined EIA (pc) \\
\hline livestock farms & 2 \\
mine & 6 \\
power plants (thermal, nuclear) & \\
wind farm & 2 \\
landfill & 4 \\
industrial factory & 3 \\
recreation facility & 4 \\
flood protection structure, reservoir & 3 \\
public utility (water, gas, electricity, sewerage) & 8 \\
thermal bath & 1 \\
railway & 2 \\
minor road & $\mathbf{1 4}$ \\
forestry road & $\mathbf{4}$ \\
express highway & $\mathbf{7}$ \\
\hline Total & 62 \\
\hline
\end{tabular}




\subsection{Examination of environmental information systems}

From the point of view of environmental impact analysis, relevant environmental descriptive databases and information systems were those that can provide environmental data concerning the individual elements of the environment. Through internet searches and the examination of printed documents (handbooks, manuals, reports), 34 databases (9 international and 25 domestic) were identified which, based on their titles, can probably be used as a potential source of data for environmental impact analysis (Table 2).

Table 2. Examined international and national information systems and databases

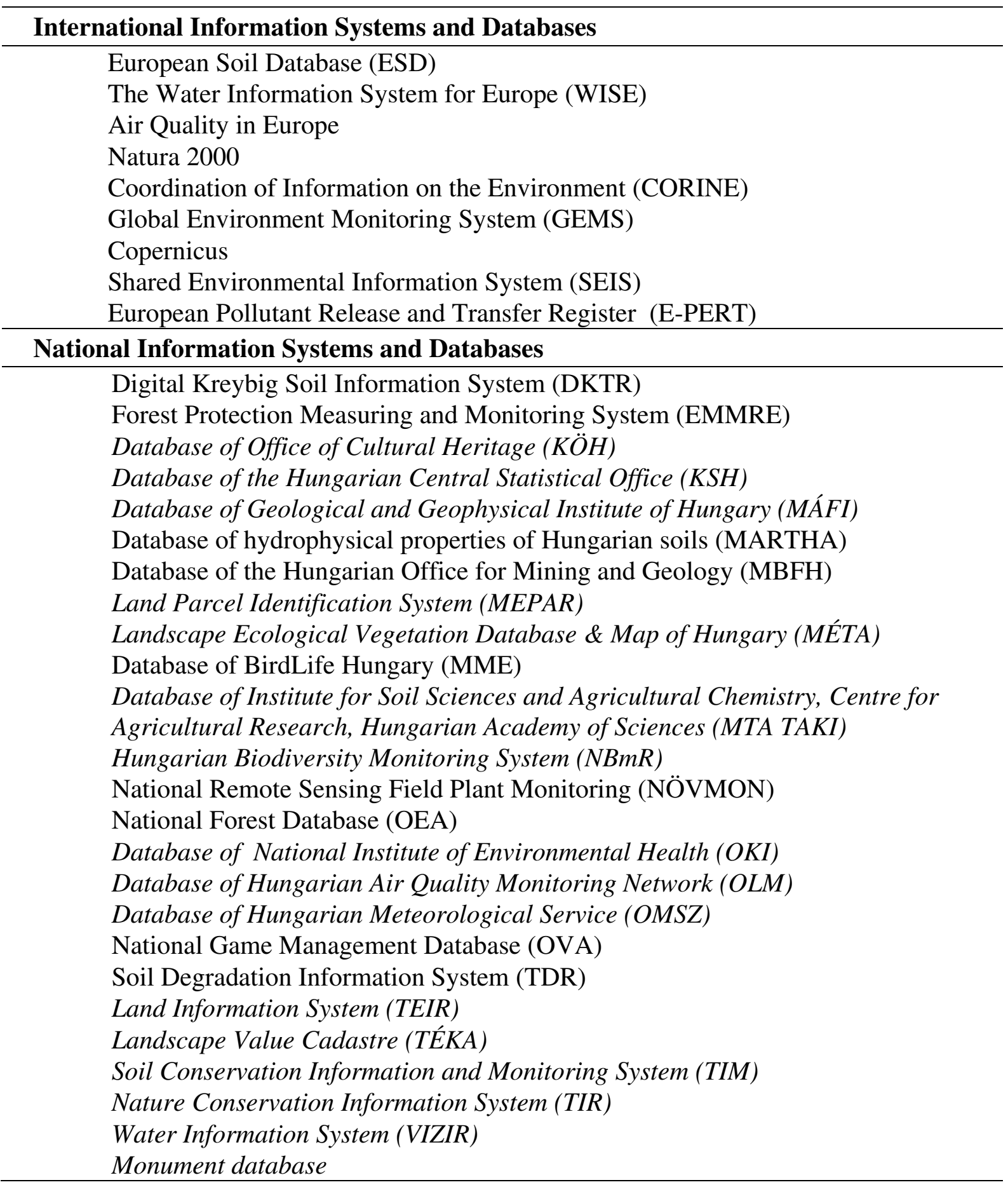


As a selection criterion for further examinations, the scope and coordination of the databases by governmental bodies (managing offices, national institutes, and ministries) were applied. From this range of databases, 16 environmental databases that were deemed the most important and most useful for our research were selected; their actual importance was defined with expert assistance. Using questionnaires (102) and personal interviews (36), professionals who, according to the database of the Environmental Professional Information System (XIR), have been conducting environmental impact studies or have been practicing expert activities of this kind were invited to participate in our research project. To attain a realistic examination of the knowledge and use of the systems, we worked towards a well-balanced representation of the different professional fields in the sample when selecting professionals to be involved. The individual professional fields were defined according to the elements and environment systems. In the analyses of the databases, the general data content, and the spatial (number and distribution of measurement points) and temporal validity and reliability of data were examined, as well as the practical application of the systems according to different points of view, such as availability, operability, software demand, download possibilities and formats, and user fees.

The list of data required by environmental impact studies was compared against the data contents of the information systems; the extent of the overlay was also examined. The achievability of data required was examined through queries of databases. This way it is possible to identify what data can be taken from which information system.

\subsection{Object classification and the elaboration of the pattern system design}

Based on the compiled list of data, an object classification of the environmental data needed for the impact studies was performed. A possible hierarchic classification is class - group type. One class can contain several groups and one group can contain several types. Based on the system worked out by the National Forestry Service (1999), the identifier of the objects was defined. The first letter in the identifier (from A to Z) stands for the object class, the second letter (from A to $\mathrm{Z}$ ) designates the group, the third and fourth character (from 01 to 99) gives the object type.

During model building, a system design was worked out. Tsichritzis and Lochovsky (1977) define a data model as "a set of guidelines for the representation of the logical organization of the data in a data base (consisting) of named logical units of data and the relationships between them". According to the concise definition by Detrekői and Szabó (1995), modelling amounts to describing the real world with a reduced set of information, in a three-step process of abstraction. In the first step, a theoretical model substitutes the real world; in this model, the entities, persons, objects, incidents and events to be used in the final model are defined. In our case, these entities are the individual system overlays of the system. In the following step, the parameters needed for the description of the theoretical model entities (geometrical and attribute data of the object types) are defined, as well as their interrelationships, that is the logical model of objects is set up. In the system design, the examination of relationships has not been touched upon, so the physical data model (third step) has not been created, which would mean the mapping and uploading the logical model in a digital environment (Czimber 2002). 


\section{RESULTS AND DISCUSSION}

\subsection{Definition of the general data requirement of environmental impact analysis}

In examining the phases and work stages of impact analysis, it was established that the surveying phase is primarily the basic state in which databases or information systems can serve as potential data sources. Consequently, in our research the analysis of data needed for the examination of the basic state of the environment was emphasized; hence, they are taken into consideration for impact assessment and evaluation.

Environmental data needed for the execution of impact studies are defined by neither foreign nor domestic laws; however, they refer to the need of certain environmental information. Pertinent literature (Tombácz - Radnai 1989, Bisset - Tomlinson 1992, Rédey et al. 2002), however, pays attention to the examination of data that can serve as the basis for characterising the environment's basic state, assessing the range of impacts, and evaluating them. Our investigations verified that in environmental impact studies characterising the basic state of the environment, general data content can be defined, which the executors of impact studies can utilize in the case of any type of establishments. Those environmental data were incorporated into our master data list, which occurred in at least three-quarters $(75 \%)$ of the studies that were investigated. Table 3 shows primary data grouped as elements of the environment.

\section{Table 3. General data of Environmental Impact Assessments}

\begin{tabular}{ll}
\hline Soil & topography, geomorphology, geological structure and bedrock, \\
& parent material, direction of slope, genetic and physical soil type, \\
& water balance, location and sensitivity of the soil layers, soil \\
& texture, pH, soil water management categories, depth of the \\
& column, soil compaction depth of the groundwater, protected \\
& geological values \\
\hline Air & $\begin{array}{l}\text { average hours of sunshine, prevailing wind direction, wind speed, } \\
\text { precipitation conditions, spatial and temporal distribution of } \\
\text { rainfall, average temperature data, air quality, background } \\
\text { contamination, protected and sensitivity categories }\end{array}$ \\
\hline Water & $\begin{array}{l}\text { size and location of surface and groundwater, water flow } \\
\text { conditions, standard flow, protected hydrological values, water } \\
\text { facilities }\end{array}$ \\
\hline Flora and fauna & $\begin{array}{l}\text { types of habitat, habitat patches, species composition, rare plant } \\
\text { communities, protected plants, animal species and population of } \\
\text { the examined area, protected animals }\end{array}$ \\
\hline Settlement, artificial \\
environment
\end{tabular}

The data requirement of a concrete type of establishment was revealed in order to check the usefulness of the general list of data. In the case of the master data of environmental impact analysis for roads, the difference with respect to the data in the general list was low (12\% altogether); thereby, we considered our verified data list generally useful. 


\subsection{Comparison of the data requirement against the data content of environmental information systems}

The number of information systems has shown an important increase in the last few years. However, data collection has become difficult because data cannot be found in a unique database, but rather are stored in several thematic databases.

In the case of soils, one of the biggest international systems is the European Soil Database. This is part of the European Soil Information System (EUSIS), a collaborative project involving all European Union and neighbouring countries and is a simplified representation of the diversity and spatial variability of the soil coverage. The database consists of both a geometrical dataset and a semantic dataset that links attribute values to the polygons of the geometrical dataset.

Thanks to the soil mapping and soil testing activities carried out for several decades, Hungary possesses soil science information that is unequalled within European countries (Várallyay et al. 2009). During the last two decades, an important part of the map-based pedological information has been digitalised and built into different special soil information systems (Szabó - Pásztor 1994). A detailed examination of three information systems related to soil has been carried out in our research. The Soil Conservation Information and Monitoring System (TIM), covering the whole area of the country, provides parameters of soil physics, soil chemistry, and soil biology from 1,236 measurement points. High-scale soil maps form the basis for the Database of Agro Topography. The map-based soil information system contains the main pedological parameters defining the site aptitude, including genetic soil type, soil-forming rock, physical soil type, clay composition, water balance properties, chemical reaction, lime state, organic stock, tilth thickness, and soil evaluation. The Hungarian Institute of Soil Sciences Database gives information about the geological structure, base rock and ground water for the whole area of the country in a map-based form.

Most of the systems involved with air are global; in these, atmospheric phenomena and climate change are stressed. Databases containing local data in relation with the air quality are rare. One such information system is Air Quality in Europe, the aim of which is to provide publically available data on the air quality in European big cities for information and comparison. In Hungary, the National Measuring Network of Air Pollution (OLM) database contains automatically and manually generated air quality data.

The last several years a significant improvement in hydrologic and environmental data availability has occurred (Beran - Piasecki 2009). The Water Information System for Europe (WISE) is a joint initiative from the European Commission (DG Environment, Eurostat, Joint Research Institute) and the European Environment Agency that aims to modernise and streamline the collection and dissemination of European water policy-related information (D'Eugenio 2007).

The development of hydrographic information in Hungary could be characterised as progress in small steps. In recent decades, work on the unified information system of the branch has been ongoing. In the directories of water management, several databases currently exist; some have been centrally developed, others are self-developed. The Water Information System (VIZIR) is a registration and processing system of water management data; its basic (descriptive) database system is the Data Store of Water Management created in 2004. The base data register of the Data Store of Water Management covers the whole Danube Basin. Currently, the national system of VIZIR comprises more than 20 databases.

Databases relevant to fauna and flora, and landscape are scarce both on the international and national levels. Among the international systems, the Coordination of Information on the Environment (CORINE) and the Natura 2000 network provide data of surface coverage and nature protection-related descriptive data for Hungary. 
The Nature Conservation Information System (TIR), working as a sub-system of the National Information System of Environmental Protection, can be considered as the principle database of domestic nature conservation. The primary objective of the system is to register nature conservation databases belonging to local and governmental authorities (landscape values: objects of geology, hydrography, botany, zoology, scenery, cultural history, ecotourism, protected natural areas) and organising these into a unified geographic information system compatible with the systems in the European Union. Because landscape value versatility, there was no unified domestic database that could collect and handle these data in a common registration system. Landscape Value Cadastre (TÉKA) is an integrated database covering the entire country. Uniting the databases of different professional organisations with the active participation of nearly a thousand civilians, it is the most detailed and most complete landscape values database.

In acquiring data regarding the built environment and humans, it was possible to rely primarily on domestic databases. Besides the Settlement Statistical Database System of the Hungarian Central Statistical Office (KSH T-STAR) and the Database of the Office of Cultural Heritage (KÖH), mention should be made of the National Regional Development and Country Planning Database. The aim of this GIS-based system is to provide objective, precise, and up-to-date information for regional development and planning activities. This system contains more than thirty-five thousand data by settlements. It is also interesting to mention the E-PRTR (European Pollutant Release and Transfer Register), which includes environmental use data for nearly 28,000 industrial establishments (Yoshida et al. 2014).

Based on their data content, the investigated domestic and international systems are applicable in the support of environmental impact studies. However, large portions of these systems consider local conditions; hence, the international databases are often insufficient to meet domestic data demand. In the case of international databases, commonly the number of measuring points has been limited; with respect to Hungary, there are considerably fewer measuring points than needed. Furthermore, several international systems call in data from the member states themselves and upload the same in its central database. Subsequently, regarding these facts in examining the possibilities of data transmission, the focus was on domestic information systems and databases.

Having compared the information systems' data content against the data requirement of EIA, it could be established that the environmental information systems include the majority $(88 \%)$ of data needed for the characterisation of the basic state of the environment, so they are indeed appropriate for the support of environmental impact studies. Following this comparison, a preliminary guide was compiled for the use of practical environmental impact analysts. This guide contains data from the impact-analysis master data that are recommendable for transfer from the information systems and databases. Source of transfer, data model, transferrable data, geometry of objects are indicated for each data point along with additional notes regarding the systems. Table 4 shows details of this guide. 
Table 4. Detail of the guide to the transfer of data

\begin{tabular}{|c|c|c|c|}
\hline Environmental data & $\begin{array}{c}\text { Data } \\
\text { source }\end{array}$ & \multicolumn{2}{|c|}{ Data model, geometry, visualization } \\
\hline \multicolumn{4}{|c|}{ SOIL } \\
\hline & MÁFI & $\begin{array}{l}\text { GIS map with activated } \\
\text { topographic layer and } \\
\text { GIS groundwater map with } \\
\text { contour lines }\end{array}$ & $\begin{array}{l}\text { area-based representation } \\
\text { (search with coordinate) }\end{array}$ \\
\hline & TAKI & $\begin{array}{l}\text { GIS map with activated } \\
\text { topographic layer }\end{array}$ & area-based representation \\
\hline & MÁFI & $\begin{array}{l}\text { GIS groundwater map with } \\
\text { contour lines }\end{array}$ & area-based representation \\
\hline & TÉKA & $\begin{array}{l}\text { map of FÖMI } \\
\text { (Hungarian Institute of } \\
\text { Geodesy, Cartography and } \\
\text { Remote Sensing) }\end{array}$ & contour representation \\
\hline & TAKI & $\begin{array}{l}\text { GIS map representation: } \\
\text { parent material }\end{array}$ & area-based representation \\
\hline & MÁFI & $\begin{array}{l}\text { GIS map representation: } \\
\text { geological structure, parent } \\
\text { material }\end{array}$ & $\begin{array}{l}\text { area-based representation } \\
\text { (search with coordinate) }\end{array}$ \\
\hline & TIM & parent material & $\begin{array}{l}\text { concerning measuring point } \\
\text { (assigned to coordinate) }\end{array}$ \\
\hline $\begin{array}{l}\text { Susceptibility to } \\
\text { erosion, deflation }\end{array}$ & TAKI & $\begin{array}{l}\text { GIS map of National Soil } \\
\text { Degradation Database: } \\
\text { susceptibility to erosion, } \\
\text { deflation }\end{array}$ & $\begin{array}{l}\text { area-based representation } \\
\text { (grayscale) } \\
\text { erosion scale: } 0-3 \\
\text { deflation scale: } 0-4\end{array}$ \\
\hline
\end{tabular}

\subsection{Object classification and definition of data models of the system design}

Due to the increasing demand for data in recent years, a number of different information systems have been created, our investigation confirms the importance of this. Most specialists involved in environmental impact analyses would require a correctly operating, user-friendly information system that includes appropriate data to facilitate their work in a meaningful way.

The provision of the required data can, however, be realised by the joint use of several systems (Barthel et al. 2008, Argent et al. 2009). Therefore, we found it necessary to define the basis of a unified information system that takes into consideration the existing ones. Knowing the environmental data necessary for describing the basic state of the environment, according to the object hierarchy, the object classes of the data model (Table 5) then the groups (Table 6), and finally the object types (Table 7) are defined. In the case of object types, the geometry of the object as well as the potential domestic sources of data supply are indicated. 
Table 5. Classes of objects

\begin{tabular}{clc}
\hline Sign of classes & Classes of object & Number of types \\
\hline A & Meteorological data & 10 \\
B & Geological and soil data & 12 \\
C & Hydrological data & 8 \\
D & Data of flora and fauna & 8 \\
E & Data of settlement and artificial environment & 8 \\
F & Data of landscape & 4 \\
\hline & & $\mathbf{5 0}$
\end{tabular}

Table 6. Groups of geological and soil data

\begin{tabular}{ccc}
\hline Sign of groups & Groups of object & Number of types \\
\hline & B - Geological and soil data & \\
\hline BA & Geological data & 3 \\
BB & Soil data & 6 \\
BC & Topography & 3 \\
\hline
\end{tabular}

Table 7. Types of Geological and soil data

\begin{tabular}{|c|c|c|c|c|c|c|}
\hline Sign & Types of object & Point & Line & Area & Surface & Source \\
\hline \multicolumn{7}{|c|}{ B - Geological and soil data } \\
\hline \multicolumn{7}{|c|}{ BA - Geological data } \\
\hline BA01 & Geological structure & & + & + & & MÁFI \\
\hline BA02 & Parent material & & & + & & MÁFI \\
\hline BA03 & Protected geological value & + & + & + & & TIR \\
\hline \multicolumn{7}{|c|}{ BB - Soil data } \\
\hline BB01 & Genetic soil type & & & + & & TAKI \\
\hline BB02 & Physical soil type & & & + & & TAKI \\
\hline BB03 & Soil water management categories & & & + & & TIM \\
\hline BB04 & Soil organic matter content & + & & & & TIM \\
\hline BB05 & Depth of the column & + & & & & TAKI \\
\hline BB06 & $\mathrm{pH}$ & + & & & & TIM \\
\hline \multicolumn{7}{|c|}{ BC - Topography } \\
\hline $\mathrm{BC} 01$ & Topography & & & + & + & TAKI \\
\hline $\mathrm{BC} 02$ & Contour lines & & & + & & MÁFI \\
\hline $\mathrm{BC} 03$ & Direction of slope & & & + & & MÁFI \\
\hline
\end{tabular}

The theoretical and logical data models of the pattern system design were set up according to our object grouping. The objects of the data model were defined in the theoretical model, while in the logical model the geometrical and attribute data of the objects were given. Beside the names of the individual overlays, the code given in the course of object classification is indicated. As an example, Table 8 illustrates the overlays of an object type of the geological and the pedologic group of object respectively. 
Table 8. Layers of logical data model (details)

\begin{tabular}{lll}
\hline PARENT MATERIAL (BA02) & \\
\hline Geometry: & vector, area & \\
$\begin{array}{l}\text { Primary data table: } \\
\text { Source: }\end{array}$ & Parent material & \\
Projection: & TAKI Agrotopo & \\
\hline \multicolumn{1}{c}{ Pungarian national grid (EOV) } & \\
\hline Name & Pescription & Type \\
PARENT MATERIAL & $\begin{array}{l}\text { type of parent material of the } \\
\text { examined area }\end{array}$ & text code \\
& & \\
\hline
\end{tabular}

\begin{tabular}{lll}
\hline $\boldsymbol{p H}(\boldsymbol{B B O 6})$ & \\
\hline Geometry: & vector, point \\
Primary data table: & pH \\
Source: & TIM \\
Projection: & Hungarian national grid (EOV) \\
\hline \multicolumn{2}{c}{ Primary data fields } \\
\hline Name & Description & Type \\
NUMBER & number of measurement point & numerical \\
TYPE & type of measurement point & enumeration \\
EOVX & x coordinate of measurement point & numerical \\
EOVY & y coordinate of measurement point & numerical \\
PH & value of pH & numerical (1 decimal place) \\
DATE & date of measurement (year, month, day) & date \\
\hline COmment: & & \\
\hline
\end{tabular}

Comment: -

The object classification illustrated in the foregoing can form a basis for later legal modifications concerning the completion of environmental impact analyses. It may also help revise the existing information systems on environmental protection and help plan their integration. When set up, the data model includes those overlays that are necessary in the course of environmental impact analysis. The creation of the system design ensures its applicability in any geological information systems serving related goals.

\section{CONCLUSIONS}

Research results support the completion of the basic state survey phase of environmental impact analysis. Completing this will make the execution and verification of environmental impact studies more efficient and less time consuming. We consider this a high priority. The set up data list and guide can both assist implementing this into practice. The current investigation focused on Hungarian information systems and impact analyses; at the same time, the pattern system design set up is feasible in any country with any geoinformatics systems.

Acknowledgements: We want to thank Levente Csóka for many helpful comments and suggestions on the manuscript and Zsolt Kovács for providing language help. 


\section{REFERENCES}

Argent, R.M. - PerRaud, J.M. - RAhMAn, J.M. - Grayson, R.B. - Podger, G.M. (2009): A new approach to water quality modelling and environmental decision support systems. Environmental Modelling \& Software 24 (7): 809-818.

BARKER, A. - WOOD, C. (1999): An evaluation of EIA system performance in eight EU countries. Environmental Impact Assessment Review 19: 387-404.

BARthel, R. - JANisch, S. - Schwarz, N. - Trifkovic, A. - Nickel, D. - SchUlz, C. - Mauser, W. (2008): An integrated modelling framework for simulating regional-scale actor responses to global change in the water domain. Environmental Modelling \& Software 23 (9): 1095-1121.

BERAN, B. - PIASECKI, M. (2009): Engineering new paths to water data. Computers and Geosciences 35: 753-760.

BIANCONI, R. - GALMARINI, S. - BELLASIO, R. (2004): Web-based system for decision support in case of emergency: ensemble modelling of long-range atmospheric dispersion of radionuclides. Environmental Modelling \& Software 19 (4): 401-411.

Bisset, R. - TomLinson, P. (1992): Monitoring and Auditing of Impacts. In: Wathern P. (ed.): Environmental Impact Assessment, Theory and Practice (Second printing). The Academic Division of Unwin Hyman Ltd., London. 117-126.

Bulla, M. (2012): A regionális fejlesztések fenntarthatósági vizsgálata; a Komplex Tudástér Modell. [Evaluation of Sustainability of the Regional Development Programmes / Policies]. In: Bulla, M. (ed.): A környezetelemzés regionális alkalmazása; a Komplex Tudástér (KxTt) modell bevezetése. Széchenyi István University, Department of Environmental Engineering, Györ. 11-47 (in Hungarian)

Bulla, M. - Keresztes, P. - Kóczy, T.L. (2004): A környezetben lejátszódó folyamatok elemzése Soft Computing módszerekkel. [Evaluation of Environmental Processes by/ using Soft Computing Methods.] In: Bulla, M. (ed.): Komplex környezetállapot-értékelő szakértői rendszerek metodikai fejlesztése. Széchenyi István University, Department of Environmental Engineering, Győr. 119-129 (in Hungarian)

CHEN, D. (2014): Application of GIS in Environmental Impact Assessment. Advanced Materials Research 989-994: 4855-4860.

CZIMBER, K. (2002): Korszerü geoinformatikai módszerek az erdészetben. [Modern Geoinformation Methods in Forestry]. PhD Thesis, Nyugat-magyarországi Egyetem, Sopron. (in Hungarian)

CSEH, S. - KovÁtSNÉ NÉMETH, M. - PÁJER, J. (2007): A környezetvédelmi engedélyezés követelményei, gyakorlata és a fejlődés iránya. [The requirements, practice and development of environmental licensing] Nyugat-magyarországi Egyetem, Kooperációs Kutató Központ, Sopron. (in Hungarian)

CSERNY, A. - KOVÁCS, Zs. - DOMOKOS, E. - RÉDEY, Á. (2009): Environmental information system for visualizing environmental impact assessment information. Environmental Science and Pollution Research 16: 36-41.

DEDRICK, J. (2010): Green IS: Concepts and issues for information systems research. Communications of the Association for Information Systems 27 (1): 173-184.

DETREKÖI, Á. - SZABÓ, GY. (1995): Térinformatika. [Geoinformatics] Nemzeti Tankönyvkiadó, Budapest. (in Hungarian)

D'Eugenio, J. - HaAstrup, P. - Jensen, S. - Wirthmann, A. - QueVauviller, P. (2007): General introduction into WISE (Water Information System for Europe). Water and Environment Journal 21 (3): 200-207.

ELEKNÉ FODOR, V. (2012): Data of Environmental Impact Assessments and Information Systems. International Scientific Conference on Sustainable Development \& Ecological Footprint, The Impact of Urbanization, Industrial and Agricultural Technologies on the Natural Environment. Sopron, Hungary. March 2012. 400.

FORMAN, RTT (2000): Estimate of the area affected ecologically by the road system in the United States. Conservation Biology (14): 31-35.

GLASSON, J. (1995): Life after the decision: the importance of monitoring in EIA. Built Environment 20 (4): 309-320. 
HERMANN, B.G. - KROEZE, C. - JAWJIT, W. (2007): Assessing environmental performance by combining life cycle assessment, multi-criteria analysis and environmental performance indicators. Journal of Cleaner Production 15: 1787-1796.

JENSEN, S. - NORUP, B. - JOCK, M. (2004): Challenging environmental reporting: from a reporting to an information system. In: Proceedings of the 18th International Conference Informatics for environmental Protection, CERN, Geneva, Switzerland. 211-214.

KOK, B. - VAN LOENEN, B. (2004): How to assess the success of National Spatial data infrastructure? Computers, Environment and Urban Systems 29 (6): 699-717.

Lagacherie, P. - McBratney, A.B. - Voltz, M. (2007): Spatial Soil Information Systems and Spatial Soil Inference Systems: Perspectives for Digital Soil Mapping. Developments in Soil Science 31: 3-21.

Lee, N. (1995): Environmental assessment in the European Union: a tenth anniversary. Project Appraisal 10 (2): 77-90.

MASSER, I. (1999): All shapes and sizes: the first generation of national spatial data infrastructures. International Journal of Geographical Information Science 13: 67-84.

PÁJER, J. (1999): A környezeti hatásvizsgálat. [Environmental Impact Assessment.] In: Thyll Sz. (ed.): Környezetgazdálkodás a mezőgazdaságban. [Environmental management in agriculture.] Mezőgazda Kiadó, Budapest. 350-368. (in Hungarian)

PÁJER, J. (2001): A környezeti hatásvizsgálatok alkalmazásának elemzése. [The analysis of application of Environmental Impact Assessment.] Erdészeti lapok 6: 189-192. (in Hungarian)

RÉDEY, Á. - MÓDI, M. - TAMASKA, L. (2002): Környezetállapot értékelés. [Environmental state evaluation.] Veszprémi Egyetemi Kiadó, Veszprém. 129 p. (in Hungarian)

RÉDEY, Á. - UTASI, A. (2004): The method of environmental impact assessment, XXI. Chemistry Teacher Conference. Pécs, Hungary

SCHIMAK, G. (2003): Environmental data management and monitoring system UWEDAT. Environmental Modeling \& Software 18: 573-580.

SZABÓ, J. - PÁSZTOR, L. (1994): Magyarország agroökológiai adatbázisa és annak környezetvédelmi felhasználási lehetőségei. [Agro-ecological database of Hungary and possibilities of environmental application.] In: National Environmental Conference proceedings, Siófok. 156-163 (in Hungarian)

TARBOTON, D.G. - HORSBURGH, J.S. - MAIDMENT, D.R. - WHITEAKER, T. - ZASLAVSKY, I. - PiASECKI, M. - Goodall, J. - Valentine, D. - WhitenaCK, T. (2009): Development of a community hydrologic information system. GEO: connexion 5 (7): 32-33.

TOMBÁCZ, E. - RADNAI, A. (1989): Ajánlás a beruházások környezeti hatásvizsgálatának tartalmára és módszertanára. [Recommendation to the content and methodology of environmental impact assessment of project.] KVM Környezetpolitikai Föosztálya, Budapest. 93 p. (in Hungarian)

Tóth, T. - BIDLÓ, A. - MÁTÉ, F. - SZÜCS, I. - DÉR, F. - Tóth, G - GAÁL, Z. - Tóth, Z. - SPEISER, F HERMANN, T. - HORVÁth, E. - NÉMETH, T. (2009): Development of an online soil valuation database. Communications in Soil Science and Plant Analysis 40: 1034-1040.

TSICHRITZIS, T. C. - LOCHOVSKY, F.H. (1977): Data base management systems. Academic Press, New York. 388 p.

VÁRAllyAy, GY. - SZABÓNÉ Kele, G. - MARTH, P. - KARKALIK, A. - ThURY, I. (2009): Magyarország talajainak állapota a talajvédelmi információs és monitoring rendszer (TIM) adatai alapján. [The state of Hungarian soils (on the basis of the data of the Soil Conservation Information and Monitoring System (TIM)] Földmủvelésügyi Minisztérium, Agrárákörnyezetvédelmi Főosztály, Budapest. 20 p. (in Hungarian)

WANG, Y.H. - ZHANG, H. - JIANG, Z.G. - ZHAO, G. (2014): Data analysis and evaluation system for resource and environmental attributes in the manufacturing process. International Journal of Computer Integrated Manufacturing 27(4): 372-381.

Yoshida, H. - Clavreul, J. - Scheutz, C. - Christensen, T. H. (2014): Influence of data collection schemes on the LifeCycle Assessment of a municipal wastewater treatment plant. Water Research 56: 292-303. 